\title{
Adipogenic and orexigenic effects of the ghrelin-receptor ligand tabimorelin are diminished in leptin-signalling- deficient ZDF rats
}

\author{
A M Holm, P B Johansen, I Ahnfelt-Rønne and J Rømer \\ Novo Nordisk A/S, Pharmacology Research, Novo Nordisk Park, DK-2760 Måløv, Denmark \\ (Correspondence should be addressed to P B Johansen, Pharmacology Research, Novo Nordisk Park, Building F6.2.30, DK-2760 Måløv, Denmark; \\ Email:pjoh@novonordisk.com)
}

\begin{abstract}
Objective: The aim was to investigate the possible interactions of the two peripheral hormones, leptin and ghrelin, that regulate the energy balance in opposite directions.

Methods: Leptin-receptor mutated Zucker diabetic fatty (ZDF) and lean control rats were treated with the ghrelin-receptor ligand, tabimorelin $(50 \mathrm{mg} / \mathrm{kg}$ p.o.) for 18 days, and the effects on body weight, food intake and body composition were investigated. The level of expression of anabolic and catabolic neuropeptides and their receptors in the hypothalamic area were analysed by in situ hybridization. Results: Tabimorelin treatment induced hyperphagia and adiposity (increased total fat mass and gain in body weight) in lean control rats, while these parameters were not increased in ZDF rats. Treatment with tabimorelin of lean control rats increased hypothalamic mRNA expression of the anabolic neuropeptide Y (NPY) mRNA and decreased hypothalamic expression of the catabolic peptide proopiomelanocortin (POMC) mRNA. In ZDF rats, the expression of POMC mRNA was not affected by treatment with tabimorelin, whereas NPY mRNA expression was increased in the hypothalamic arcuate nucleus.

Conclusion: This shows that tabimorelin-induced adiposity and hyperphagia in lean control rats are correlated with increased hypothalamic NPY mRNA and decreased POMC mRNA expression. The elimination of tabimorelin-induced adiposity and hyperphagia in ZDF rats may be due to lack of POMC mRNA downregulation. In conclusion, we suggest that ghrelin-receptor ligands exert their adipogenic and orexigenic effects via hypothalamic mechanisms that are dependent on intact leptin-receptor signalling.
\end{abstract}

European Journal of Endocrinology 150 893-904

\section{Introduction}

Ghrelin, a recently identified gastric hormone, is the endogenous ligand for the growth hormone secretagogue receptor (GHS-R) (1), now also known as the ghrelin receptor. It is well established that both ghrelin and synthetic ghrelin-receptor ligands increase food intake and change the energy balance, including a reduction in fat utilization that results in increased body weight and adiposity in animals $(2-7)$. Upon fasting in rats, ghrelin mRNA is upregulated in the ghrelinproducing oxyntic glands of the stomach, and the plasma ghrelin level is elevated (8).

The ghrelin-receptor mRNA is expressed in the pituitary gland and in several areas of the brain $(9,10)$. In the hypothalamus, the ghrelin-receptor mRNA is expressed in neuropeptide Y (NPY)/agouti-related protein (AGRP)-, leptin-receptor- and growth hormone-releasing hormone (GHRH)-containing neurons (9, 11-14). Systemic administration of ghrelin or ghrelin-receptor ligands induces expression of the immediate-early gene c-Fos in many of these arcuate neurons $(12,15,16)$. The central effects of ghrelin may in part be mediated via NPY neurons in the arcuate nucleus, as NPY mRNA and AGRP mRNA expression in these neurons is increased after administration of ghrelin icv $(5,17,18)$, and pre-treatment with antibodies and antagonists of NPY and AGRP abolishes ghrelin-induced feeding (5).

In contrast to ghrelin, administration of leptin inhibits appetite and adiposity, and augments energy expenditure $(19,20)$. Ghrelin-induced food intake is suppressed when ghrelin and leptin are co-injected icv (5). Likewise, leptin-induced inhibition of food intake can be reversed by ghrelin (17). The level of leptin in the circulation correlates with the degree of adiposity, and, at least in rodents, leptin has been shown to function as a peripheral signal in a negative feedback loop to hypothalamic nuclei involved in the regulation of energy balance $(21,22)$. The plasma 
leptin level reflects the state of the energy balance; that is, fasting decreases plasma leptin while overfeeding increases it (23). These opposing effects of leptin and ghrelin on appetite and adiposity are thought to involve arcuate neurons. Leptin inhibits NPY/AGRP- and activates pro-opiomelanocortin (POMC)-containing neurons in the arcuate nucleus (20), and leptin-induced reduction of hypothalamic NPY mRNA is abolished by co-injection of ghrelin (17).

In the present study, we have investigated the possible interactions of the two peripheral hormones, leptin and ghrelin, that regulate the energy balance in opposite directions. Leptin-receptor mutated Zucker diabetic fatty (ZDF) and lean control rats were treated with the ghrelin-receptor ligand, tabimorelin (NNC 26-703) (7), and the effects on body weight, food intake and body composition were investigated. Finally, the metabolic effects were correlated to changes induced in the hypothalamic pathways, as reflected by the level of expression of anabolic and catabolic hypothalamic neuropeptides and receptors.

\section{Materials and methods}

\section{Animals and tissue}

Obese male ZDF (fa/fa), and lean male control rats (fa/+) were obtained from Genetic Models, Inc (Indianopolis, USA). The rats arrived at 12 weeks of age, and were housed under standardized environmental conditions $\left(18-22^{\circ} \mathrm{C}\right.$; a 12 -h light/dark cycle, lights on at $0600 \mathrm{~h}$; and two rats in each cage). The rats were given free access to water and a diet of Purina 5008 chow (PMI, Nutrition International, Richmond, IN, USA).

The rats were randomly assigned to four experimental groups (vehicle and tabimorelin) according to body weight, $n=11-12$ in each group. From 13 weeks of age and the following 18 days, the rats were treated daily p.o. with tabimorelin $(50 \mathrm{mg} / \mathrm{kg})$ or vehicle (saline), and body weight $(n=11-12$ in each group) and food intake (per cage) were measured $(n=5-6$ in each group).

The rats were killed at day 18. Blood was collected under isoflurane anaesthesia by cardiac puncture. Samples were taken in standard $\mathrm{K}_{3}$ EDTA glass tubes (Vacutainer, VWR International, Albertslund, Denmark), and plasma was isolated. The rats $(n=5$ in each group) were decapitated, and the brains were quickly removed, frozen in 2-methylbutane and kept at $-80^{\circ} \mathrm{C}$ until use. Coronal sections of $14 \mu \mathrm{m}$ through the hypothalamic area were cut with a Jung CM3000 cryostat (Leica, Glostrup, Denmark), collected on SuperFrost/Plus slides (Menzel-Gläser, Braunschweig, Germany) and stored at $-80^{\circ} \mathrm{C}$ until further processing. The care and use of laboratory animals was according to an animal licence complying with federal regulations for use of animals in research (the Danish Committee for Animal Research). The study design is illustrated in Fig. 1.

For anatomical orientation, every fifteenth slide was counterstained with haematoxylin and eosin (HE). Sections through the paraventricular nucleus (PVN), and the middle and the caudal part of the arcuate nucleus were selected. These sections were located at a distance of approximately $-1.80,-3.00$ and $-3.70 \mathrm{~mm}$ from Bregma, according to the rat brain atlas of Paxinos and Watson (24).

\section{Dual energy X-ray absorptiometry (DEXA)}

At day 14, the body composition was determined by DEXA (pDEXA Sabre, Stratec Medizintechnic; Norland Medical Systems, Phörzheim, Germany) in rats fasted

Treatment: tabimorelin or vehicle

Food intake and body weight

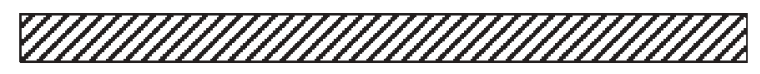

Body composition

by dual energy X-ray absorptiometry

Plasma leptin

In situ hybridization
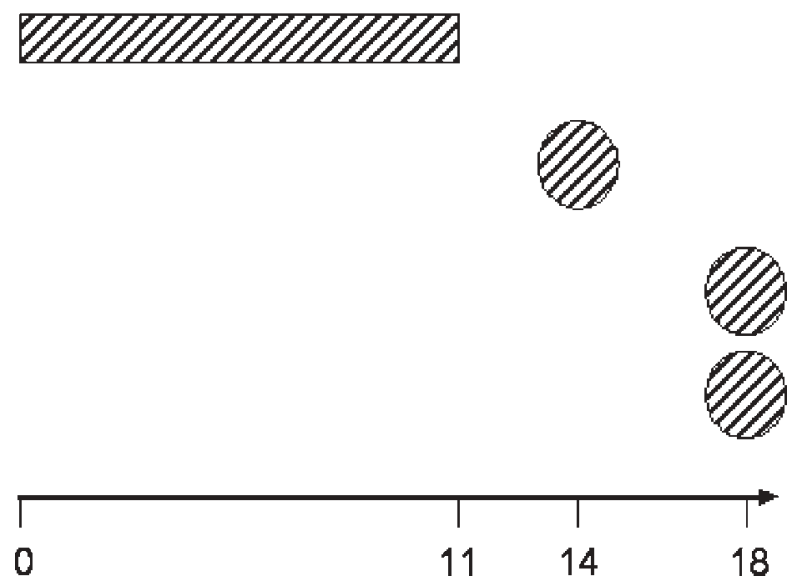

Figure 1 Study design. Lean control rats and ZDF rats were treated daily with tabimorelin or vehicle for 18 days. Food intake and body weight were measured daily from day 0 to day 11 . Body composition was determined by dual energy X-ray absorptiometry (DEXA) at day 14. Rats were killed at day 18, plasma was collected for leptin analysis and brains were collected for in situ hybridization. 
for $18 \mathrm{~h}$. The rats were anaesthesized with a combination of Hypnorm and Dormicum (both diluted $1: 1$ in distilled water, mixed $1: 1$ and administered $2 \mathrm{ml} / \mathrm{kg}$ i.p.) (Hypnmorm, Janssen Animal Health, Belgium; Dormicum, Roche, Switzerland). The instrument settings used were as follows: a scan speed of $40 \mathrm{~mm} / \mathrm{s}$, a resolution of $1.0 \times 1.0 \mathrm{~mm}$, and automatic/ manual histogram width estimation $(n=11-12$ in each group).

\section{Plasma leptin}

Plasma leptin was measured at day 18 with a commercially available mouse leptin enzyme-linked immunosorbent assay kit (Crystal Chemical, Chicago, IL, USA), showing over $95 \%$ cross-reactivity to rat leptin.

\section{Plasmid preparation}

Rat NPY, POMC, AGRP, MC3-R, MC4-R, and ghrelinreceptor cDNA fragments were generated by RT-PCR, and each of these was subcloned into the pCR-Script $\mathrm{SK}(+)$ cloning vector, which was subsequently transformed into Epicurian Coli XL1-Blue MRF'Kan cells (Stratagene, La Jolla, CA, USA).

NPY The rat NPY cDNA fragment (bp 75-422, GenEMBL no. m20373) was generated by RT-PCR, using the primers 5'-AGG TAA CAA ACG AAT GGG and 5'-GAT GAG ATG AGA TGT GGG. The plasmid was linearized with NotI or BamHI for transcription with T7 (antisense probe) or T3 (sense probe) RNA polymerase respectively.

POMC The rat POMC cDNA fragment (bp 162-626, GenEMBL No. j00759) was generated by RT-PCR with the primers $5^{\prime}$-CCT TGA CTG AAA ATC CCC and 5'-TTC TTG AAG AGC GTC ACC. The plasmid was linearized with SacI and BamHI for transcription with T7 (sense probe) and T3 (antisense probe) RNA polymerase respectively.

Ghrelin-receptor The rat GHS-R 1A fragment (bp 236-3125, excluding the intron at bp 791-2824) was generated with the primers $5^{\prime}$-GGC CGC GGC TCT ACC TGT CCA GCA TGG C and 5'-GTT GAT GCT CGA CTT TGT CC. The plasmids containing the ghrelinreceptor fragments were linearized with SacI for transcription with T7 (antisense probe) and BamHI for transcription with T3 (antisense probe) RNA polymerase.

AGRP The rat AGRP cDNA fragment (bp 546-803, GenEMBL no. AF206017) was generated by RT-PCR with the primers 5'-ATG CTG ACT GCA ATG TTG CTG AGT and 5'-ATT GAA GAA GCG GCA GTA GCA CGT. The plasmid was linearized with NotI and EcoR1 for transcription with T7 (sense probe) and T3 (antisense probe) RNA polymerase respectively.

MC3-R The rat MC3-R cDNA fragment (bp 458-888, GenEMBL no. x70667) was generated by RT-PCR with the primers 5'-TGG AAA ACA TCC TGG TGA TCC TGG and 5'-AAG AAC ATG GTG ATG AGG CAC ACG. The plasmid was linearized with BamHI for transcription with T3 (antisense probe) and NotI for transcription with $\mathrm{T} 7$ (sense probe) polymerase.

MC4-R The rat MC4-R cDNA fragment (bp 441-918, GenEMBL no. u67863) was generated by RT-PCR with the primers $5^{\prime}$-GTC AGA AAC CAT CGT CAT CAC CC and 5'-GCA GAC AAC AAA CAC TCC AAT CAG. The plasmid was linearized with BamHI and NotI for transcription with T3 (antisense probe) and T7 (sense probe) RNA polymerase respectively.

\section{Probe preparation}

For the synthesis of radiolabelled probes, linearized plasmids were transcribed in $40 \mathrm{mM}$ Tris, $\mathrm{pH} 7.5$; $6 \mathrm{mM} \mathrm{NaCl}_{2} ; 2 \mathrm{mM}$ spermidine; $10 \mathrm{mM} \mathrm{NaCl} ; 10 \mathrm{mM}$ DTT; $1.6 \mathrm{U} / \mu \mathrm{l}$ RNAsin; $0.5 \mathrm{mM}$ each of CTP, ATP and GTP; $1.6 \mathrm{pmol} / \mathrm{ml}$ linearized plasmid; $1.6 \mathrm{U} / \mu \mathrm{l}$ RNA polymerase (Promega, Madison, WI, USA); and

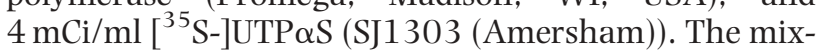
ture was incubated for $2 \mathrm{~h}$ at $37^{\circ} \mathrm{C}$, and the DNA template was digested with $40 \mathrm{ng} / \mu \mathrm{l}$ DNAse (Promega). Next, $0.8 \mathrm{mg} / \mathrm{ml}$ yeast t-RNA was added, and after $15 \mathrm{~min}$ at $37^{\circ} \mathrm{C}$, the probe was extracted with phenol and chloroform/isoamylalcohol and precipitated with ethanol. Finally, the RNA probes were hydrolysed in $100 \mathrm{mM}$ bicarbonate buffer $(\mathrm{pH} 10.2)$ to obtain an average length of 100 nucleotides, neutralized, precipitated again and solubilized in 50\% $10 \mathrm{mM}$ DTT and $50 \%$ deionized formamide. The activity was then counted in a Packard Tricarb 4530.

\section{In situ hybridization with ${ }^{35}$ S-labelled probes}

The brain sections were subjected to in situ hybridization ( $n=5$ in each group). The specific activity of the probe was 500000 c.p.m./ $\mu$ l in the final hybridization mixture. The sections were washed in 50\% formamide, $1 \mathrm{x}$ SALTS $(300 \mathrm{mM} \mathrm{NaCl}, 10 \mathrm{mM}$ Tris $(\mathrm{pH}$ 6.8), $10 \mathrm{mM} \mathrm{NaPO}_{4}, 5 \mathrm{mM}$ EDTA, $0.02 \%$ Ficoll 400 , $0.02 \%$ polyvinylpyrolidone and $0.02 \%$ BSA) and $10 \mathrm{mM}$ DTT for $1 \mathrm{~h}$ at $57^{\circ} \mathrm{C}$ followed by $1 \mathrm{~h}$ at $62^{\circ} \mathrm{C}$ (NPY, POMC, AGRP, MC3-R and MC4-R probes) or $1 \mathrm{~h}$ at $62^{\circ} \mathrm{C}$ followed by $1 \mathrm{~h}$ at $67^{\circ} \mathrm{C}$ (ghrelin-receptor probe). After RNAse A treatment $(20 \mu \mathrm{g} / \mathrm{ml}$ RNase A (Boehringer Mannheim, Mannheim, Germany) in 0.5 $\mathrm{M} \mathrm{NaCl}, 10 \mathrm{mM}$ Tris-Cl (pH 7.2), $1 \mathrm{mM}$ EDTA) at $37^{\circ} \mathrm{C}$ for $30 \mathrm{~min}$, the sections were washed for $30 \mathrm{~min}$ in $0.1 \times \mathrm{SSC}(1 \times \mathrm{SSC}$ contains $150 \mathrm{mM} \mathrm{NaCl}$ and $15 \mathrm{mM}$ with $1 \mathrm{mM}$ DTT at room temperature). 
After hybridization, sections were exposed on BetaMax film (Amersham). Sections hybridized with the NPY, POMC and AGRP probes were exposed for 3 days, sections hybridized with the ghrelin-receptor probe for 2 weeks and sections hybridized with the MC3-R and MC4-R probes for 5 weeks.

\section{Image analysis}

The hybridization signals in the brain sections were determined from the autoradiographic films. Images were scanned and analysed using the NIH-Image software (Scion Image) by an observer blinded to the treatment/genetic background of individual animals. The arcuate nucleus, ventromedial hypothalamus (VMH) and PVN of the hypothalamus were identified in different sections, and the relative optical density within the selected areas was measured. The background was subtracted by measuring the relative optical density within an area of the brain section without signal.

\section{Statistics}

Results are shown as means \pm S.E.M. Statistical analysis was done by two-tailed, unpaired Student's $t$-test, and differences between groups were considered significant at $P<0.05$.

\section{Results}

\section{Effects of tabimorelin on body weight and food intake in lean control rats are diminished in ZDF rats}

The effects of 11 days p.o. treatment with tabimorelin $(50 \mathrm{mg} / \mathrm{kg})$ on body weight and food intake were measured in male leptin-receptor mutated ZDF and lean control rats 13-16 weeks old. During the 11 days' treatment, all groups gained body weight (Fig. 2A). The gain in body weight after 11 days' tabimorelin treatment was significantly increased only in lean control rats compared with vehicle (from $298.7 \pm 2.2 \mathrm{~g}$ to $348.0 \pm 2.4 \mathrm{~g}$ at day 11 in tabimorelin-treated rats compared with $300.8 \pm 2.9 \mathrm{~g}$ to $338.4 \mathrm{~g}$ in vehicle-treated rats. The gain in body weight was $49.3+1.6 \mathrm{~g}$ vs $37.6+1.5 \mathrm{~g} ; P<0.01)$. The gain in body weight was not significantly increased in ZDF rats (from $335.3 \pm 4.6 \mathrm{~g}$ to $362.3 \pm 6 \mathrm{~g}$ compared with $333.4 \pm 5.2 \mathrm{~g}$ to $354.7 \pm 6.2$. The gain in body weight was $26.1 \pm 3.2 \mathrm{~g}$ vs $21.3 \pm 2.1 \mathrm{~g}$; NS).

Total food consumption was significantly increased in lean control rats after 11 days' treatment with

A

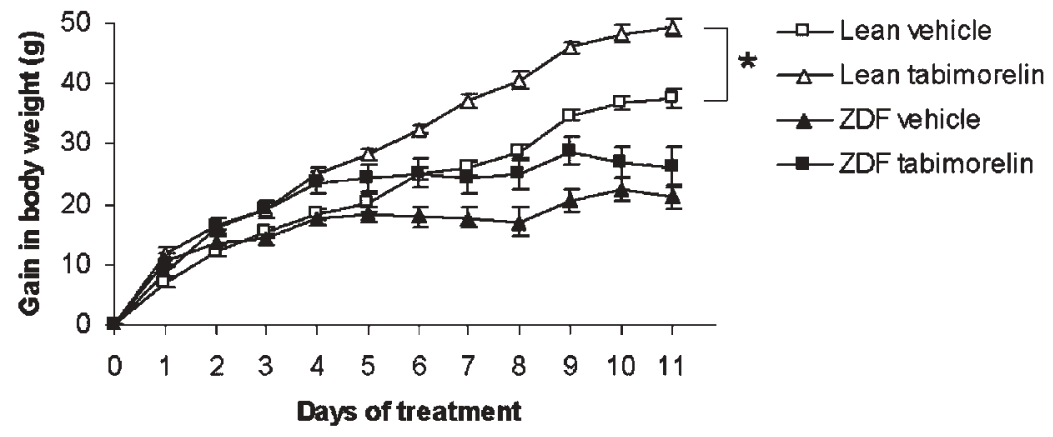

B

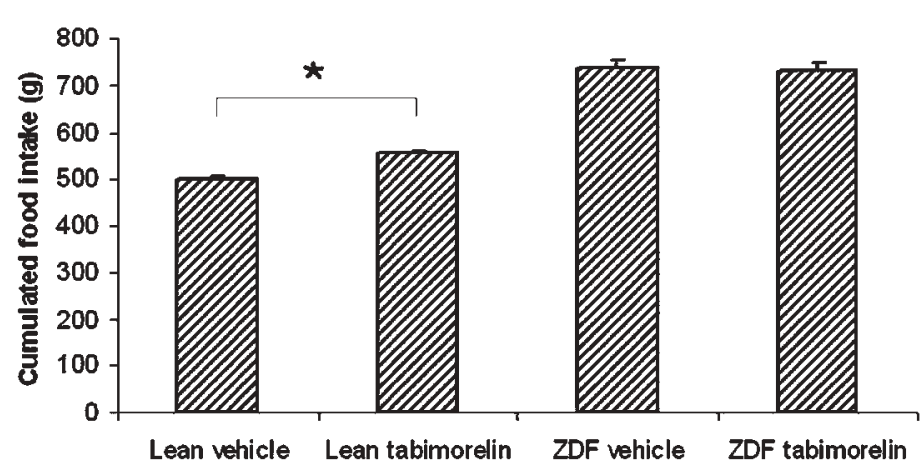

Figure 2 Body weight and food intake in lean control rats and ZDF rats after vehicle or tabimorelin treatment. (A) Gain in body weight during 11 days' treatment of lean control rats and ZDF rats with vehicle or tabimorelin (50 mg/kg p.o.; $n=11-12$ per group). (B) Food consumption measured as cumulative food intake in the same rats. Two rats were housed in each cage. $n=5-6$ per group. Data are expressed as mean \pm S.E.M. ${ }^{\star} P<0.05$. 
tabimorelin compared with vehicle $(554.4 \pm 4.5 \mathrm{~g}$ vs $500.2 \pm 6.1 \mathrm{~g} ; P<0.05)$, but was not changed after tabimorelin treatment in ZDF rats $(731.8 \pm 17.1 \mathrm{~g}$ vs $736.8 \pm 17.0$ g; NS) (Fig. 2B).

\section{Effects of tabimorelin on body composition in lean control rats, but not $\mathrm{ZDF}$ rats}

Body composition (total body fat, and lean and bone mass) was measured by in vivo DEXA (Fig. 3A). In lean control rats, administration of tabimorelin for 14 days compared with vehicle increased the percentage of total body fat $(10.1 \pm 0.4 \%$ vs $7.9 \pm 0.5 \% ; P<0.05)$ and decreased lean mass $(87.1 \pm 0.5 \%$ vs $89.2 \pm 0.6 \%$; $P<0.05$ ), but did not have any effect on bone mass $(2.6 \pm 0.0 \%$ vs $2.6 \pm 0.0 \%$; NS). In ZDF rats, treatment with tabimorelin for 14 days did not affect percentage of total body fat $(32.8 \pm 0.9 \%$ vs $31.3 \pm 1.2 \%$; NS), lean mass $(66.0 \pm 1.2 \%$ vs $66.0 \pm 1.2 \%$; NS) or bone mass $(2.3 \pm 0.03 \%$ vs $2.3 \pm 0.0 \%$; NS).

\section{Tabimorelin increases leptin level in lean control rats, but not in $\mathrm{ZDF}$ rats}

Treatment with tabimorelin for 18 days increased plasma leptin level in lean control rats compared with vehicle $(2.08 \pm 0.31 \mathrm{ng} / \mathrm{ml}$ vs $0.85 \pm 0.14 \mathrm{ng} / \mathrm{ml}$;
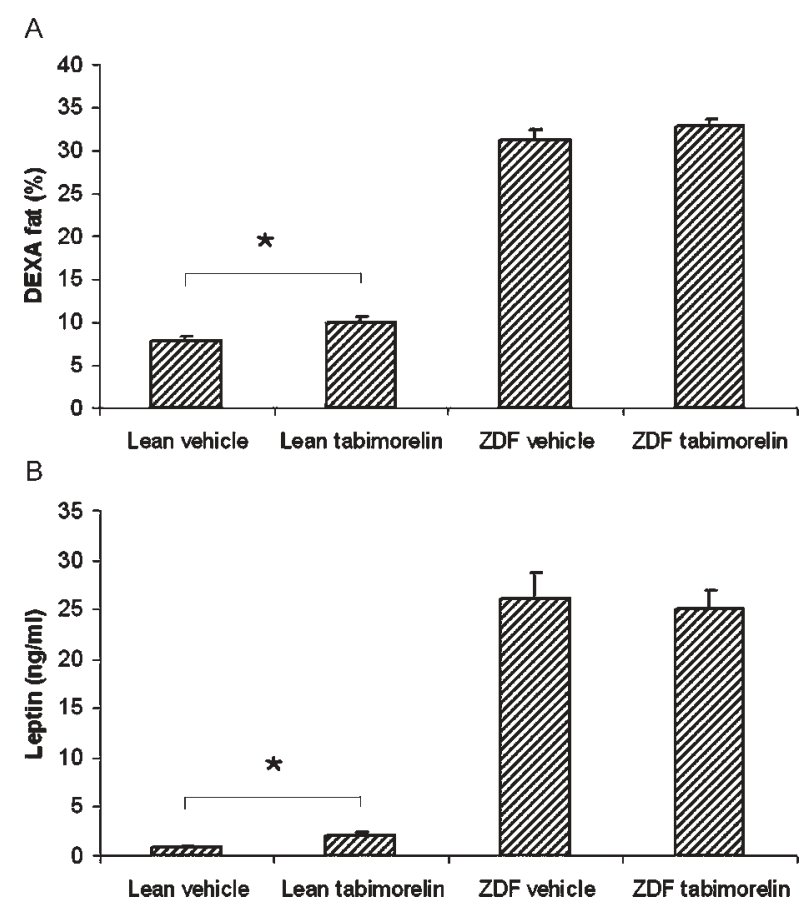

Figure 3 Body fat and plasma leptin concentration in lean control rats and ZDF rats after vehicle or tabimorelin treatment. (A) Total body fat measured by dual energy X-ray absorptiometry (DEXA) of lean control rats and ZDF rats treated with vehicle or tabimorelin $50 \mathrm{mg} / \mathrm{kg}$ p.o. for 14 days. (B) Plasma leptin concentration in trunk blood in the same rats after 18 days' treatment. Data are expressed as mean \pm S.E.M., $n=11-12$ per group. ${ }^{\star} P<0.05$.
$P<0.01)$. No effect on the plasma leptin level was observed after tabimorelin treatment in ZDF rats compared with ZDF rats treated with vehicle $(25.06 \pm$ $1.78 \mathrm{ng} / \mathrm{ml}$ vs $26.10 \pm 2.62 \mathrm{ng} / \mathrm{ml}$; NS) (Fig. 3B).

\section{Tabimorelin increases NPY mRNA expression level in ZDF rats and lean control rats}

NPY mRNA was detected by in situ hybridization of coronal sections from the hypothalamus. Two different levels through the middle and caudal part of the arcuate nucleus were analysed $(n=5)$. In both sections, the strongest expression was seen in the arcuate nucleus and in the latter also in the dorsomedial hypothalamus (DMH) (Fig. 4). The expression in the lean control rats treated with vehicle was set to $100 \%$. Treatment with tabimorelin significantly increased the expression of NPY mRNA in the caudal part of the arcuate nucleus in both lean control rats $(121.8 \pm 4.3 \%$ vs $100.0 \pm 6.8 \% ; P<0.05)$ and ZDF rats $(167.2 \pm 15.4 \%$ vs $119.7 \pm 4.8 \% ; P<0.05)$. No upregulation was detected in the section through the middle part of the arcuate nucleus or in the DMH in either lean control rats (arcuate nucleus: $84.8 \pm 7.5$ vs $100.0 \pm 7.8 \%$; NS) (DMH: $113.1 \pm 9.8 \%$ vs $100.0 \pm 7.8 \%$; NS) or ZDF rats (arcuate nucleus: $127.4 \pm 9.6 \%$ vs $112.3 \pm 7.4 \%$; NS) (DMH: $101.8 \pm 7.0 \%$; vs $102.3 \pm 7.7 \%$; NS). The data are summarized in Table 1.

\section{Tabimorelin decreases POMC mRNA expression level in lean control rats, but not in ZDF rats}

The expression of POMC mRNA was exclusively detected in the middle part of the arcuate nucleus. POMC mRNA expression was significantly reduced after tabimorelin treatment in lean control rats (74.8 $\pm 1.7 \%$ vs $100.0 \pm 6.3 \% ; P<0.05)$, but was not affected by tabimorelin treatment in ZDF rats $(49.8 \pm 4.5 \%$ vs $47.7 \pm 4.0 \%$; NS) (Fig. 5 ).

\section{Increased expression of ghrelin-receptor mRNA in lean control rats, but not in ZDF rats}

Expression of ghrelin-receptor mRNA was detected in the arcuate nucleus and VMH. Tabimorelin treatment increased the expression of ghrelin-receptor mRNA in the middle part of the arcuate nucleus in lean control rats $(156.8 \pm 11.2 \%$ vs $100.0 \pm 9.0 \% ; P<0.01)$, but not in ZDF rats $(153.8 \pm 26.4 \%$ vs $184.9 \pm 13.7 \%$; NS). No upregulation was detected in the caudal part of the arcuate nucleus in either lean control rats $(118.6 \pm 5.2 \%$ vs $100.0 \pm 12.6 \%$; NS) or ZDF rats (153.4 $\pm 17.1 \%$ vs $117.9 \pm 5.5 \%$; NS) after tabimorelin compared with vehicle treatment. The expression of ghrelin-receptor mRNA in the VMH (data not shown) or specifically in the dorsomedial part of the VMH, which has the strongest expression of ghrelin-receptor 

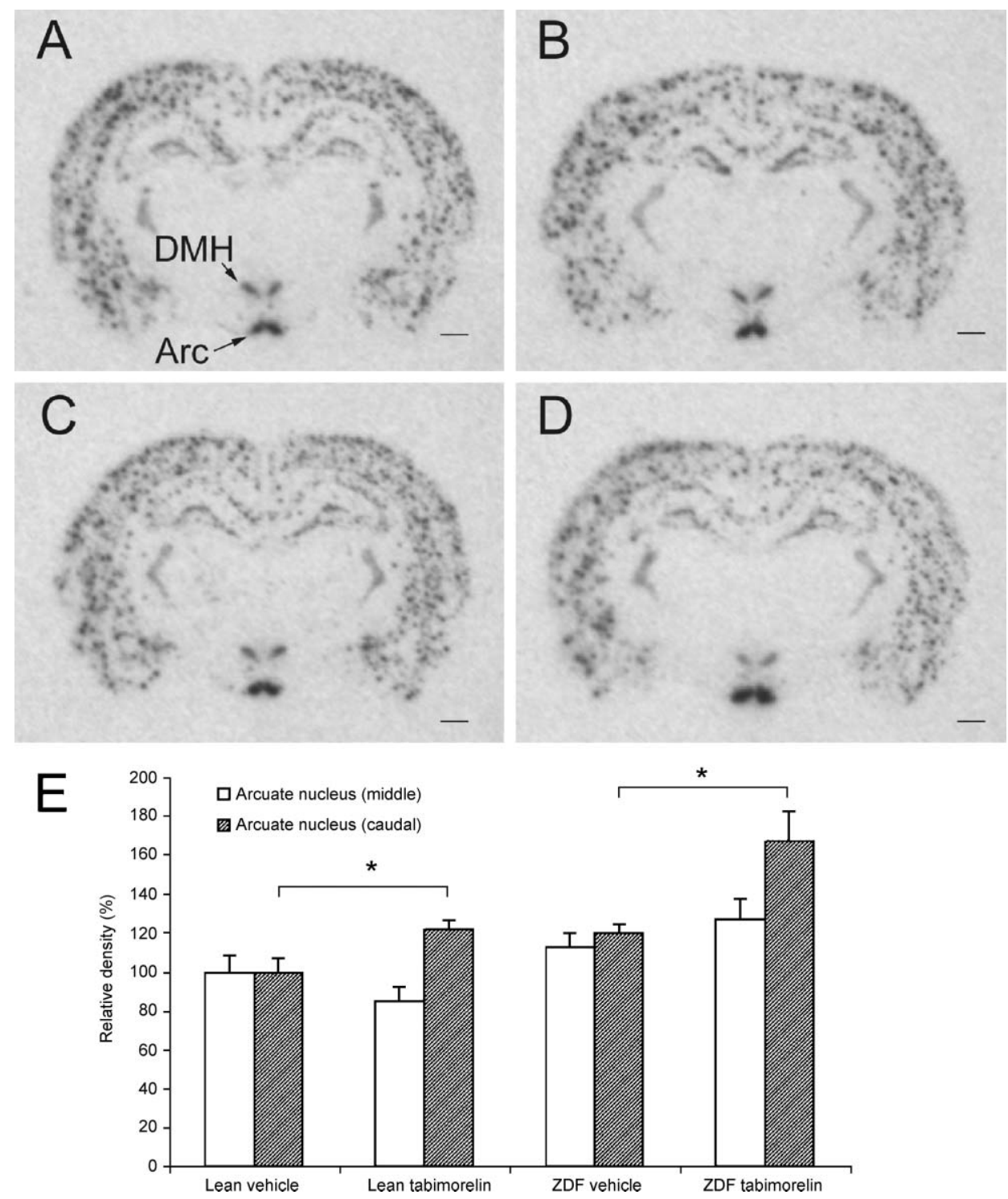

Figure 4 NPY mRNA expression in lean control rats and ZDF rats after vehicle or tabimorelin treatment. In situ hybridization of NPY mRNA in coronal brain sections representing the caudal part of the arcuate nucleus (Arc) and dorsomedial hypothalamus (DMH) from lean control (A and $B)$ and ZDF rats (C and D) treated with vehicle $(A$ and $C)$ or tabimorelin $(50 \mathrm{mg} / \mathrm{kg} \mathrm{p.o.)} \mathrm{for} 18$ days $(B$ and $D)$ respectively. Bars $=1000 \mu \mathrm{m}$. (E) Quantitative image analysis of NPY mRNA expression in the middle and caudal part of Arc. The expression in the lean control rats treated with vehicle is set to $100 \%$. Autoradiographic film was exposed for 3 days. Data are expressed as mean \pm S.E.M., $n=5$ in each group. ${ }^{\star} P<0.05$.

mRNA, was not affected by tabimorelin treatment in either lean control $(100.7 \pm 7.7 \%$ vs $100.0 \pm 13.3 \%$; $\mathrm{NS})$ or ZDF rats $(63.6 \pm 11.9 \%$ vs $67.6 \pm 6.0 \%$; NS) (Fig. 6).

\section{No changes in the expression of AGRP mRNA, MC3-R MRNA and MC4-R MRNA in ZDF rats and lean control rats following tabimorelin treatment}

A very distinct expression of AGRP mRNA was detected in the middle and caudal arcuate nucleus. No differences could be detected after tabimorelin treatment in lean control rats $(92.6 \pm 6.9 \%$ vs $100.0 \pm 7.1 \%$; NS) or ZDF rats (125.4 $\pm 13.4 \%$ vs $98.4 \pm 8.9 \%$; NS).

In the hypothalamus, the expression of MC3-R mRNA was observed in $\mathrm{VMH}$ and in the arcuate nucleus (Fig. 7), while the expression of MC4-R mRNA was detected in PVN. The expression of the MC3-R mRNA in VMH was not affected by tabimorelin treatment in lean control $(113.2 \pm 6.3 \%$ vs $100.0 \pm 5.6 \%$; NS) or ZDF rats (133.1 $\pm 4.0 \%$ vs $124.6 \pm 7.3 \%$; NS), and no change was detected in the arcuate nucleus in lean control rats $(116.0 \pm 5.6 \%$ vs $100.0 \pm 6.5 \%$; NS) or ZDF rats $(95.7 \pm 9.0 \%$ vs $101.6 \pm 8.9 \%$; NS). Likewise, no differences in the expression of MC4-R mRNA in PVN in the 
Table 1 Summary of the effects of tabimorelin treatment compared to vehicle in lean control rats and ZDF rats. Effects of 18 days' tabimorelin treatment (50 mg/kg p.o.) compared to vehicle in lean control rats and ZDF rats on gain in body weight, cumulative food intake, total body fat, plasma leptin level and the expression of NPY, POMC and ghrelin-receptor mRNA in the hypothalamic arcuate nucleus.

\begin{tabular}{lccccccc}
\hline & Body weight & Food intake & Fat (\%) & Plasma leptin & NPY mRNA & POMC mRNA & Ghrelin-receptor mRNA \\
\hline Lean controls & $\uparrow$ & $\uparrow$ & $\uparrow$ & $\uparrow$ & $\uparrow$ & $\downarrow$ & $\uparrow$ \\
ZDF rats & $\leftrightarrow$ & $\leftrightarrow$ & $\leftrightarrow$ & $\leftrightarrow$ & $\uparrow$ & $\leftrightarrow$ & $\leftrightarrow$ \\
\hline
\end{tabular}

lean control rats (PVN: $102.2 \pm 7.8 \%$ vs $100.0 \pm 6.7 \%$; NS) or ZDF rats (PVN: $98.1 \pm 4.3 \%$ vs $106.2 \pm 3.4 \%$; NS) were detected after tabimorelin treatment.

\section{Discussion}

Treatment with the ghrelin-receptor ligand tabimorelin has an adipogenic (increased total fat mass and body weight) and an appetite-increasing effect in lean control rats. This is in contrast to the lack of effect of tabimorelin treatment on these parameters in ZDF rats. In accordance with the anabolic effects, tabimorelin treatment of lean control rats increased hypothalamic expression of mRNA for the anabolic neuropeptide NPY and decreased hypothalamic expression of mRNA for the catabolic peptide POMC. In ZDF rats, the expression of POMC mRNA was not affected by treatment with tabimorelin, whereas NPY mRNA expression was increased in the hypothalamic arcuate nucleus. In addition, the expression of ghrelin-receptor mRNA was increased in the arcuate nucleus in lean control rats, but not in ZDF rats, after tabimorelin treatment.

In this study, tabimorelin is shown to increase food intake and body weight, and induce obesity in lean control rats. This result is in accordance with previous studies demonstrating that ghrelin and ghrelin-receptor ligands increase food intake and change the energy balance, including a reduction in fat utilization, resulting in increased body weight and adiposity in rodents when administered either peripherally or centrally $(2-7,25)$.

ZDF rats have a mutation in the gene encoding the leptin receptor, resulting in abnormal energy balance characterized by hyperphagia, decreased energy expenditure and increased adiposity (26). The ZDF rat is a well-established animal model, suitable for studies of interactions between ghrelin and leptin, since lean rats $(\mathrm{fa} /+)$ with intact leptin signalling can be used as a control group. Both vehicle-treated ZDF rats and lean control rats gained body weight during this study. However, tabimorelin treatment increased the body weight only in lean control rats compared with vehicle treatment. The trend to a transiently increased body weight seen in the ZDF rats is consistent with the previous finding of a transient increase in body weight until 7 days after administration of the ghrelin receptor agonist G7039 to ZDF rats (27). In this context, it should be mentioned that the growth-promoting properties of ghrelin receptor agonists have been noted in both pups (28) and mature rats (29), and is therefore not influenced by body weight per se. Furthermore, it is likely that the fat load of the ZDF rats does not prevent further fat deposition, because the fat percentage is much higher in, for example, the Zucker obese rat. This hypothesis could be tested by administration of a ghrelin receptor agonist to diet-induced obese rats without a leptin receptor defect, and with a fat load of approximately the same size as that of the ZDF rat.

Ghrelin-receptor ligand-induced adiposity seems to be GH- and NPY-independent, since the adipogenic effect has also been demonstrated in GH-deficient dwarf rats and in NPY-knockout mice $(4,6)$. Other studies have focused on the opposite effects of ghrelin and leptin on food intake and induction of hypothalamic NPY mRNA (5, 17). However, this clearly demonstrates that a ghrelin-receptor ligand does not induce adiposity or orexigenic effect in leptin-resistant ZDF rats.

Our findings of the hypothalamic expression patterns of NPY, POMC, ghrelin-receptor, AGRP, MC3-R and MC4-R mRNA agree with previously published results $(9-11,30-33)$. NPY and POMC are expressed in adjacent, but distinct, subpopulations of arcuate nucleus neurons $(14,34)$. Moreover; these NPY neurons co-express mRNA encoding AGRP (14). The leptin receptor is expressed by both POMC and NPY/AGRP neurons in the arcuate nucleus, and both subpopulations of neurons are regulated by leptin, but in an opposing manner. Thus, NPY/AGRP neurons are inhibited and POMC neurons are activated by leptin $(34,35)$.

The majority of ghrelin-receptor mRNA-expressing neurons co-express NPY, while only very few neurons co-express POMC (9). The orexigenic action of ghrelin has been demonstrated to be due to activation of the NPY/AGRP hypothalamic pathway (5, 12, 15-18). This study demonstrates for the first time that the orexigenic properties of ghrelin-receptor ligands are associated with decreased hypothalamic POMC mRNA expression, and are not alone dependent on increased hypothalamic NPY mRNA expression. Our results indicate that the opposing signals from the peripheral hormones ghrelin and leptin converge in arcuate neurons. Ghrelin and ghrelin-receptor ligands stimulate the orexigenic NPY pathway and inhibit the anorexigenic POMC pathway, while leptin stimulates POMC and inhibits NPY pathways. 

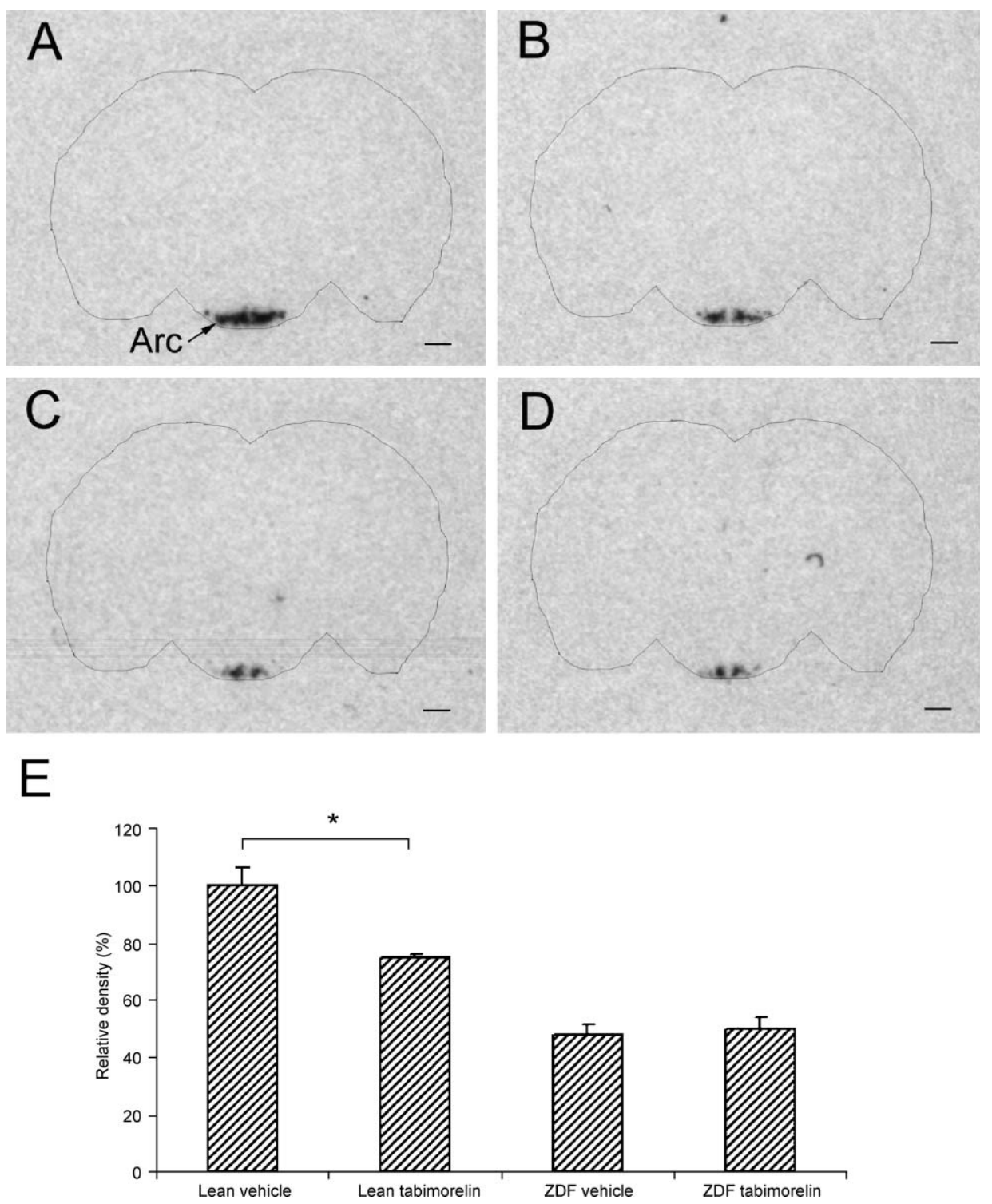

Figure 5 POMC mRNA expression in lean control rats and ZDF rats after vehicle or tabimorelin treatment. In situ hybridization of POMC mRNA in coronal brain sections representing the middle part of the arcuate nucleus (Arc) from lean control rats $(A$ and $B)$ and ZDF rats $(C$ and $D)$ treated with vehicle $(A$ and $C)$ or tabimorelin $(50 \mathrm{mg} / \mathrm{kg}$ p.o.) for 18 days $(B$ and $D)$ respectively. Bars $=1000 \mu \mathrm{m}$. (E) Quantitative image analysis of POMC mRNA expression in the Arc. The expression in the lean control rats treated with vehicle is set to $100 \%$. Autoradiographic film was exposed for 3 days. Data are expressed as mean \pm S. E.M., $n=5$ in each group. ${ }^{\star} P<0.05$.

In ZDF rats, tabimorelin treatment increased hypothalamic NPY mRNA expression but did not affect POMC mRNA expression. A similar pattern has been observed in obese fa/fa rats after fasting (36). Downregulation of POMC mRNA seems to be an important mediator of the adipogenic effect of ghrelin and ghrelin-receptor ligands. Apparently, the observed upregulation of hypothalamic NPY mRNA alone after ghrelin-receptor ligand treatment cannot increase obesity or food intake further in obese hyperphagia ZDF rats.

Treatment with tabimorelin increased the expression of the ghrelin-receptor mRNA in the middle, but not in the caudal, part of the arcuate nucleus in lean control rats, while the expression of the ghrelin-receptor mRNA was not affected in ZDF rats after tabimorelin treatment. Therefore, lean control rats may become more sensitive to ghrelin and ghrelin-receptor ligand treatment than ZDF rats, and this may thus partly explain why tabimorelin treatment can induce obesity only in lean control rats, and not in ZDF rats. The expression of NPY mRNA was increased in the caudal part, but not in the middle part $1100-1200 \mu \mathrm{m}$ more anterior in the arcuate nucleus. It is therefore very unlikely that it is the same neurons that upregulate the ghrelin-receptor mRNA and NPY mRNA. Tschöp et al. did not find increased hypothalamic NPY mRNA 

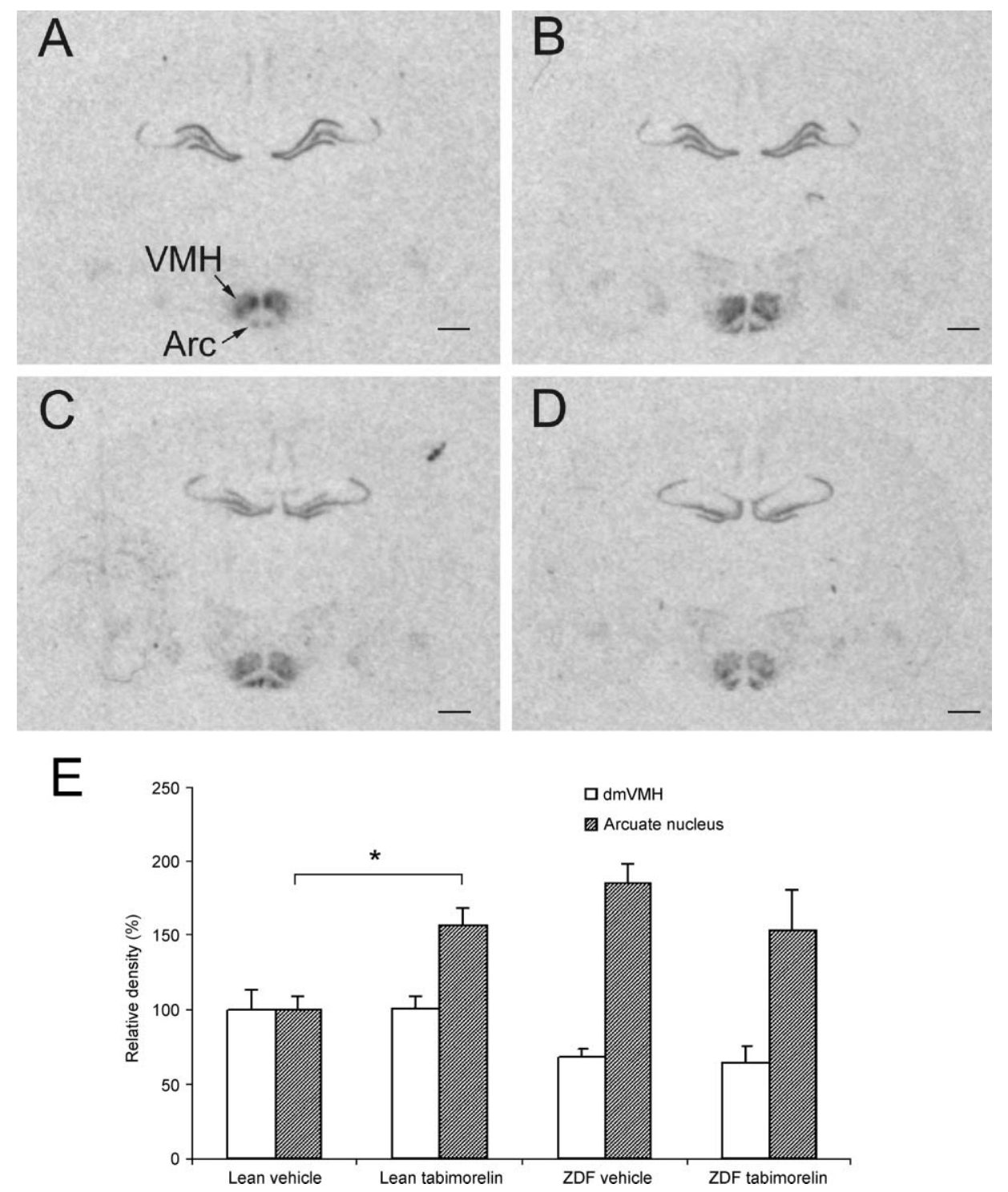

Figure 6 Ghrelin-receptor mRNA expression in lean control rats and ZDF rats after vehicle or tabimorelin treatment. In situ hybridization of ghrelin-receptor mRNA in coronal brain sections representing the middle part of the arcuate (Arc) and ventromedial hypothalamic (VMH) nuclei from lean control $(A$ and $B)$ and ZDF rats $(C$ and $D)$ treated with vehicle $(A$ and $C)$ or tabimorelin $(50 \mathrm{mg} / \mathrm{kg} \mathrm{p.o.)} \mathrm{for} 18$ days $(B$ and $D)$ respectively. Bars $=1000 \mu \mathrm{m}$. (E) Quantitative image analysis of ghrelin-receptor mRNA expression in the Arc and dorsomedial part of $\mathrm{VMH}$ (dmVMH). The expression in the lean control rats treated with vehicle is set to $100 \%$. Autoradiographic film was exposed for 14 days. Data are expressed as mean \pm S.E.M., $n=5$ in each group. ${ }^{\star} P<0.05$.

expression in wild-type mice after 18 days' treatment with another ghrelin-receptor ligand, GHRP-2 (6). However, this conclusion was based on the analysis of RNA extracts of the whole hypothalamus, where differences between separate hypothalamic areas, such as the middle and caudal part of the arcuate nucleus, may be levelled out.

The expression of hypothalamic AGRP mRNA is not affected by tabimorelin treatment in either lean control rats or ZDF rats. NPY and AGRP mRNA have previously been demonstrated to be upregulated after ghrelin administration (18, 37-39), and co-expressed in neurons in the arcuate nucleus (14). The expression levels of NPY and AGRP have been demonstrated to be regulated in parallel during fasting $(14,36)$. Therefore, it may be unexpected that NPY and AGRP mRNA are not regulated similarly in this study. However, it has previously been reported that fa/fa rats after fasting only upregulate NPY mRNA, and not AGRP mRNA (36). As mentioned above, Tschöp et al. did not detect increased hypothalamic NPY mRNA expression in wild-type mice after 18 days' GHS treatment, and they detected only a tendency toward increased hypothalamic AGRP mRNA expression (6). A detailed analysis of the time-course effects of tabimorelin on hypothalamic AGRP mRNA is needed to clarify 

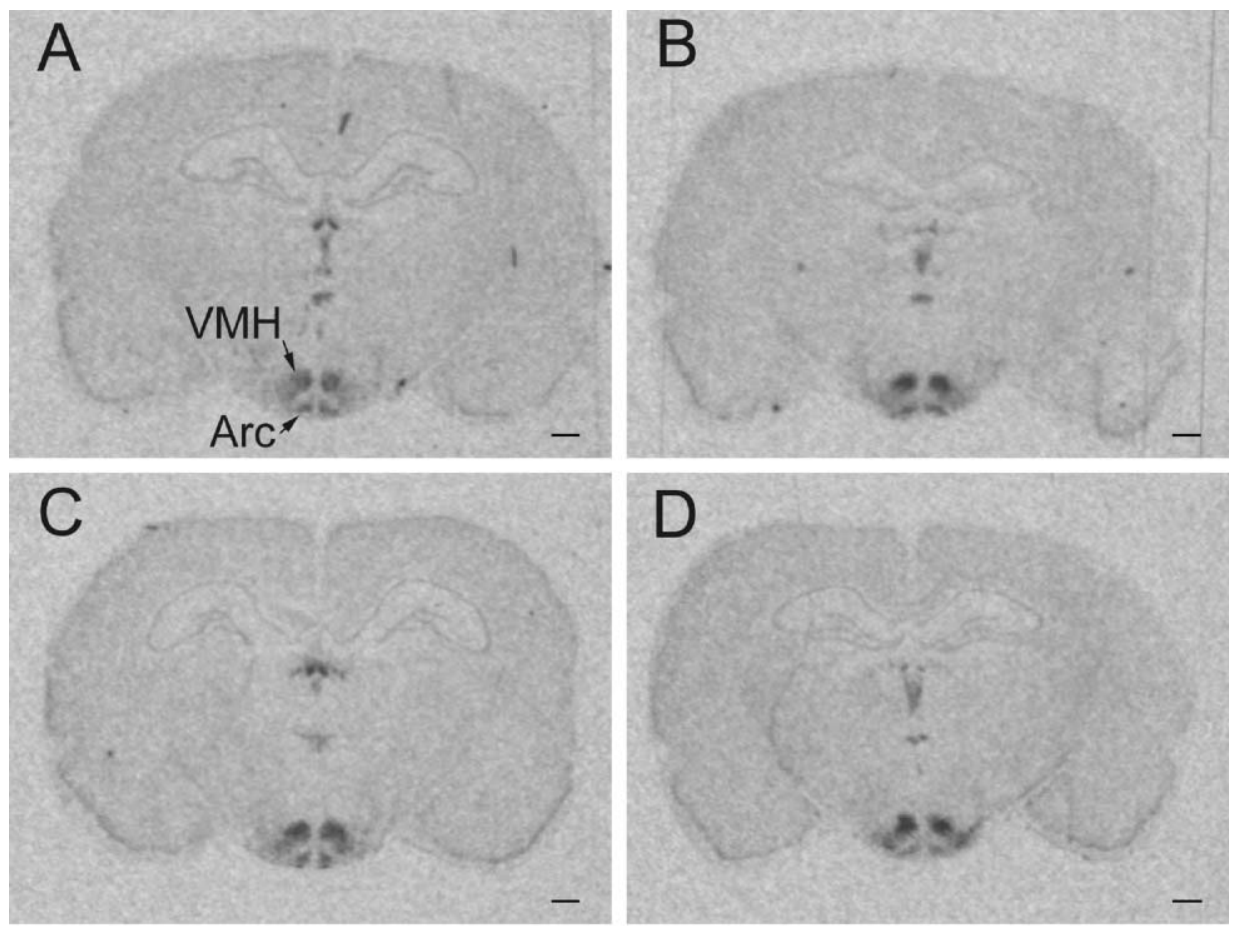

$E$

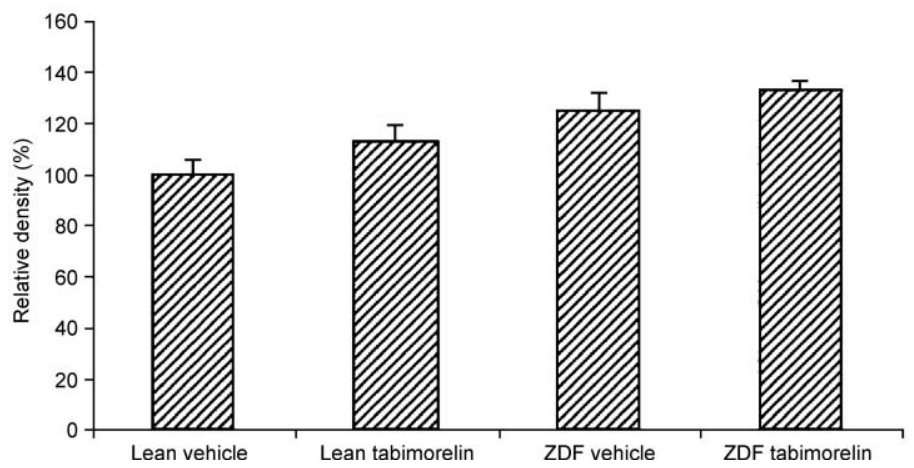

Figure 7 MC3-R mRNA expression in lean control rats and ZDF rats after vehicle or tabimorelin treatment. In situ hybridization of MC3R mRNA in coronal brain sections representing the middle part of the arcuate (Arc) and ventromedial hypothalamic (VMH) nuclei from lean control rats $(A$ and $B)$ and ZDF rats $(C$ and $D)$ treated with vehicle $(A$ and $C)$ or tabimorelin $(50 \mathrm{mg} / \mathrm{kg}$ p.o.) for 18 days $(B$ and $D)$ respectively. Bars $=1000 \mu \mathrm{m}$. (E) Quantitative image analysis of MC3-R mRNA expression in the VMH. The expression in the lean control rats treated with vehicle is set to $100 \%$. Autoradiographic film was exposed for 35 days. Data are expressed as mean \pm S.E.M., $n=5$ in each group. ${ }^{*} P<0.05$.

whether AGRP mRNA is changed at different time points in ZDF rats lacking functional leptin receptor. Taken together, our data indicate that NPY and AGRP are differentially regulated in leptin-receptor-deficient animals. The expression of the two melanocortin receptors, MC3-R mRNA and MC4-R mRNA, was not affected by tabimorelin treatment in either lean control rats or ZDF rats. This indicates that, despite the downregulation of POMC following tabimorelin treatment in control rats, the distal part of the melanocortin system is not directly implicated in the ghrelin and ghrelin-receptor ligand pathways.
In conclusion, our results suggest that the ghrelinreceptor ligand tabimorelin exerts its adipogenic and orexigenic effects via hypothalamic mechanisms that oppose hypothalamic leptin-receptor mediated signalling. It is well established that leptin reduces food intake by stimulation of POMC mRNA and inhibition of NPY mRNA expression $(14,34)$. This study demonstrates that tabimorelin-induced adiposity and hyperphagia are correlated with increased hypothalamic NPY mRNA expression and decreased POMC mRNA expression, and that these effects are dependent on intact leptin-receptor signalling. 


\section{Acknowledgements}

Pia Rothe, Aase Vinterby, Merete Achen, Elene JH Carlsen, Nanna KN Hansen and Hanne Pia Kryger are thanked for excellent technical assistance. This work was supported by a grant from the European Union (QLRT-1999-02038).

\section{References}

1 Kojima M, Hosoda H, Date Y, Nakazato M, Matsuo H \& Kangawa K. Ghrelin is a growth-hormone-releasing acylated peptide from stomach. Nature $1999 \mathbf{4 0 2} 656-660$.

2 Tschöp M, Smiley DL \& Heiman ML. Ghrelin induces adiposity in rodents. Nature $2000 \mathbf{4 0 7} 908-913$.

3 Wren AM, Small CJ, Ward HL, Murphy KG, Dakin CL, Taheri S et al. The novel hypothalamic peptide ghrelin stimulates food intake and growth hormone secretion. Endocrinology 2000141 4325-4328.

4 Lall S, Tung LYC, Ohlsson C, Jansson JO \& Dickson SL. Growth hormone $(\mathrm{GH})$-independent effects of $\mathrm{GH}$ secretagogues on adiposity. Biochemical and Biophysical Research Communications $2001280132-138$.

5 Nakazato M, Murakami N, Date Y, Kojima M, Matsuo H, Kangawa $\mathrm{K}$ et al. A role for ghrelin in the central regulation of feeding. Nature 2001409 194-198.

6 Tschöp M, Statnick MA, Suter TM \& Heiman ML. GH-releasing peptide-2 increases fat mass in mice lacking NPY: indication for a crucial mediating role of hypothalamic agouti-related protein. Endocrinology $2002 \mathbf{1 4 3} 558-568$.

7 Hansen BS, Raun K, Nielsen KK, Johansen PB, Hansen TK, Peschke B et al. Pharmacological characterisation of a new oral GH secretagogue, NN703. European Journal of Endocrinology $1999141180-189$.

8 Toshinai K, Mondal MS, Nakazato M, Date Y, Murakami N, Kojima M et al. Upregulation of ghrelin expression in the stomach upon fasting, insulin-induced hypoglycemia, and leptin administration. Biochemical Biophysical Research Communications 2001 281 1220-1225.

9 Willesen MG, Kristensen P \& Rømer J. Co-localization of growth hormone secretagogue receptor and NPY mRNA in the arcuate nucleus of the rat. Neuroendocrinology $1999 \quad \mathbf{7 0}$ 306-316.

10 Guan XM, Yu H, Palyha OC, McKee KK, Feighner SD, Sirinathsinghji DJ et al. Distribution of mRNA encoding the growth hormone secretagogue receptor in brain and peripheral tissues. Molecular Brain Research 199748 23-29.

11 Broberger C, Johansen J, Johansson C, Schalling M \& Hökfelt T. The neuropeptide Y/agouti gene-related protein (AGRP) brain circuitry in normal, anorectic, and monosodium glutamatetreated mice. PNAS 199895 15043-15048.

12 Traebert M, Riediger T, Whitebread S, Scharrer E \& Schmid HA. Ghrelin acts on leptin-responsive neurones in the rat arcuate nucleus. Journal of Neuroendocrinology $2002 \mathbf{1 4}$ $580-586$.

13 Tannenbaum GS, Lapointe M, Beaudet A \& Howard AD. Expression of growth hormone secretagogue-receptors by growth hormone-releasing hormone neurons in the mediobasal hypothalamus. Endocrinology $19981394420-4423$.

14 Hahn TM, Breininger JF, Baskin DG \& Schwartz MW. Coexpression of Agrp and NPY in fasting-activated hypothalamic neurons. Nature Neuroscience $1998 \mathbf{1} 271-272$.

15 Dickson SL \& Luckman SM. Induction of c-fos messenger ribonucleic acid in neuropeptide $\mathrm{Y}$ and growth hormone $(\mathrm{GH})$-releasing factor neurons in the rat arcuate nucleus following systemic injection of the GH secretagogue, GH-releasing peptide-6. Endocrinology $1997138771-777$.
16 Hewson AK \& Dickson SL. Systemic administration of ghrelin induces Fos and Egr-1 proteins in the hypothalamic arcuate nucleus of fasted and fed rats. Journal of Neuroendocrinology $2000121047-1049$.

17 Shintani M, Ogawa Y, Ebihara K, Aizawa-Abe M, Miyanaga F, Takaya K et al. Ghrelin, an endogenous growth hormone secretagogue, is a novel orexigenic peptide that antagonizes leptin action through the activation of hypothalamic neuropeptide Y/Y1 receptor pathway. Diabetes $2001 \mathbf{5 0} 227-232$.

18 Kamegai J, Tamura H, Shimizu T, Ishii S, Sugihara H \& Wakabayashi I. Chronic central infusion of ghrelin increases hypothalamic neuropeptide $\mathrm{Y}$ and Agouti-related protein mRNA levels and body weight in rats. Diabetes 200150 2438-2443.

19 Friedman JM \& Halaas JL. Leptin and the regulation of body weight in mammals. Nature 1998395 763-770.

20 Schwartz MW, Woods SC, Porte D, Seeley RJ \& Baskin DG. Central nervous system control of food intake. Nature $2000 \mathbf{4 0 4}$ 661-671.

21 Halaas JL, Gajiwala KS, Maffei M, Cohen SL, Chait BT, Rabinowitz $\mathrm{D}$ et al. Weight-reducing effects of the plasma protein encoded by the obese gene. Science $1995269543-546$.

22 Pelleymounter MA, Cullen MJ, Baker MB, Hecht R, Winters D et al. Effects of the obese gene product on body weight regulation in ob/ob mice. Science $1995269540-543$.

23 Kolaczynski JW, Considine RV, Ohannesian J, Marco C, Opentanova I, Nyce MR et al. Responses of leptin to short-term fasting and refeeding in humans: a link with ketogenesis but not ketones themselves. Diabetes 1996 45 1511-1515.

24 Paxinos C \& Watson C. In The Rat Brain in Stereotaxic Coordinates, 2nd edn. San Diego, CA: Academic Press, 1986.

25 Wren AM, Small CJ, Abbott CR, Dhillo WS, Seal LJ, Cohen MA et al. Ghrelin causes hyperphagia and obesity in rats. Diabetes $2001502540-2547$.

26 Ahima RS \& Flier JS. Leptin. Annual Review of Physiology 200062 413-437.

27 Clark R, Thomas GB, Mortensen DL, Won WB, Ma YH, Tomlinson EE, Fairhall KM \& Robinson IC. Growth hormone secretagogues stimulate the hypothalamic-pituitary-adrenal axis and are diabetogenic in the Zucker diabetic fatty rat. Endocrinology 1997138 4316-4323.

28 Bowers CY, Momany FA, Reynolds GA \& Hong A. In vitro and in vivo activity of a new synthetic hexa peptide that acts on the pituitary to specifically release growth hormone. Endocrinology 1984 $1141537-1545$.

29 Johansen PB, Nowak J, Skjaerbaek C, Flyvbjerg A, Andreassen TT, Wilken M \& Orskov H. Ipamorelin, a new growth-hormonereleasing peptide, induces longitudinal bone growth in rats. Growth Hormone IGF Research 1999 9 106-113.

30 Morris BJ. Neuronal localisation of neuropeptide Y gene expression in rat brain. Journal of Comparative Neurology 1989 $290358-368$.

31 Gee CE, Chen CL, Roberts JL, Thompson R \& Watson SJ. Identification of proopiomelanocortin neurones in rat hypothalamus by in situ cDNA-mRNA hybridization. Nature $1983 \mathbf{3 0 6}$ 374-376.

32 Roselli-Rehfuss L, Mountjoy KG, Robbins LS, Mortrud MT, Low MJ, Tatro JB et al. Identification of a receptor for gamma melanotropin and other proopiomelanocortin peptides in the hypothalamus and limbic system. PNAS $1993 \mathbf{9 0}$ $8856-8860$.

33 Mountjoy KG, Mortrud MT, Low MJ, Simerly RB \& Cone RD. Localization of the melanocortin-4 receptor (MC4-R) in neuroendocrine and autonomic control circuits in the brain. Molecular Endocrinology 19948 1298-1308.

34 Baskin DG, Breininger JF \& Schwartz MW. Leptin receptor mRNA identifies a subpopulation of neuropeptide $\mathrm{Y}$ neurons activated by fasting in rat hypothalamus. Diabetes $1999 \mathbf{4 8}$ $828-833$. 
35 Cheung CC, Clifton DK \& Steiner RA. Proopiomelanocortin neurons are direct targets for leptin in the hypothalamus. Endocrinology $1997 \mathbf{1 3 8} 4489-4492$.

36 Korner J, Savontaus E, Chua SC, Leibel RL \& Wardlaw SL. Leptin regulation of Agrp and Npy mRNA in the rat hypothalamus. Journal of Neuroendocrinology 200113 959-966.

37 Kamegai J, Tamura H, Shimizu T, Ishii S, Sugihara H \& Wakabayashi I. Central effect of ghrelin, an endogenous growth hormone secretagogue, on hypothalamic peptide gene expression. Endocrinology 2000141 4797-4800.

38 Yoshihara F, Kojima M, Hosoda H, Nakazato M \& Kangawa K. Ghrelin: a novel peptide for growth hormone release and feeding regulation. Current Opinion in Clinical Nutrition and Metabolic Care $20025391-395$.

39 Seoane LM, López M, Tovar S, Casanueva FF, Señaris R \& Diéguez C. Agouti-related peptide, neuropeptide Y, and somatostatinproducing neurons are targets for ghrelin actions in the rat hypothalamus. Endocrinology $2003 \mathbf{1 4 4} 544-551$.

Received 30 September 2003

Accepted 18 February 2004 